\title{
ENVIRONMENTAL MANAGEMENT FOR THE CONTROL OF PARASITIC PROTOZOAN DISEASES
}

\author{
THIERRY A. FREYVOGEL \\ Swiss Tropical Institute, Socinstrasse 57, CH-4051, Basel, Switzerland
}

(Received 30 September 1985)

\begin{abstract}
When parasitic disease, whether of protozoan or other origin, gets out of control, it is mostly due to increasing, rarely decreasing, human population pressure and/or to changes of human behaviour. By his various activities man changes his environment; it thus appears logical to try to control disease by environmental management. The goal thereof is not to eradicate disease but rather to establish a new, tolerable equilibrium.

Environmental management has been shown to alleviate the situation. It ought not, however, be seen as a unique measure; it must rather be an integral part of a comprehensive plan which includes various other approaches simultaneously, such as medical treatment, vector and intermediate host control, improvement of water supply and nutrition, improvement of housing and sanitary conditions.

Environmental management is thus closely interlinked with traditional occupations, customs and beliefs. In addition, environmental management, in the long run, can be undertaken only by local populations. These, therefore, need information and motivation, information through acceptable health education, motivation through long-lasting government support, from all levels and with all departments concerned co-operating, and possibly through appropriate, unobtrusive expatriate assistance.
\end{abstract}

Key Words: Environmental management, parasitic diseases, community participation, support from outside

\begin{abstract}
Résumé Quand une maladie parasitaire, qu'elle soit d'origine protozoaire ou autre, échappe à tout contrôle, cela est essentiellement dû à une pression plus forte, rarement plus faible, de la population humaine et/ou à des changements dans le comportement humain. De par ses activités variées l'homme modifie son environnement; il paraît donc logique d'essayer de contrôler ces maladies par la gestion de l'environnement. Le but de cette dernière n'est pas d'éradiquer les maladies mais plutôt d'établir un nouvel et tolérable équilibre.

Il a été montré que la gestion de l'environnement allège la situation. Il ne faut cependant pas la regarder comme une mesure unique, il faut plutôt la prendre comme partie intégrante d'un plan général qui inclut simultanément, différent types d'approches telles que traitement médical, contrôle des vecteurs et des hôtes intermédiaires, amélioration des ressources en eau et nourriture, amélioration des habitations et des conditions sanitaires.

La gestion de l'environnement est de ce fait étroitement liée aux occupations traditionnelles, aux coutumes et aux croyances. De plus, la gestion de l'environnement, à longue échéance, peut seulement être entreprise par les populations locales. Celles-ci, par conséquent, ont besoin d'informations et de motivation; informations au travers d'une éducation sanitaire acceptable, motivation au travers d'un support à long terme du gouvernement, à tous les niveaux et avec la coopération de tous les départements concernés, et si possible au travers d'une assistance appropriée et discrète par des expatriés.
\end{abstract}

Mots Clefs: Aménagement de l'environnement, maladies parasitaires, participation communautaire, soutien extérieur

\section{INTRODUCTORY REMARKS}

\section{Interdependence of human health and environment}

Although man-parasite-vector or man-parasiteintermediate host systems may be subject to lifelong, stimulating scientific laboratory research, the epidemiology of parasitic diseases will not be understood unless those systems are seen in the context of the environment, common to all partners involved in the transmission processes. In addition, one has to bear in mind that most often in tropical countries man harbours not one but several parasite species; the ecosystem of which man is part, accordingly gets more complex.

There is close relationship between man and vectors or intermediate hosts on one side and environment on the other (Fig. 1). Furthermore, man, by his various activities, both large and small scale, modifies the environment, including its climate. Environment, in turn, influences man who again, will adapt his mode of life to changing environmental conditions. Since such changing conditions will also affect vectors and intermediate hosts, it seems logical that one tries to use changes brought about in the environment purposely, to create conditions adverse to vectors and/or intermediate hosts, i.e. to apply 'environmental management'.

\section{The role of environmental management in view of human population growth}

Environmental management, could be a useful tool to preserve a tolerable equilibrium between parasites and man under more or less stable conditions, changing moderately and possibly in a self-repeating fash- 


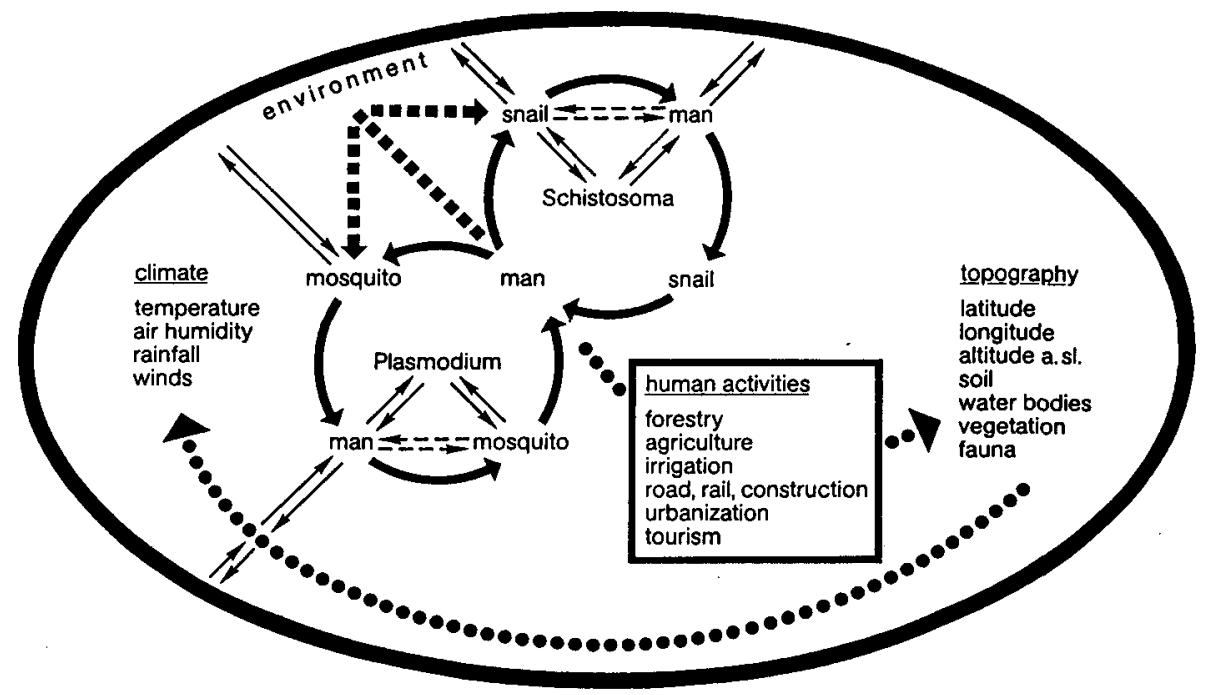

Fig. 1. Man-parasite-environment interrelations.

ion, in the context of, for example fluctuating migrations. However, one must be aware of the fact that there is increasing human population pressure (Table 1), at present particularly in warm countries. This calls for increased environmental management in an attempt to maintain the equilibrium, or to regain it where it is lost due to overpopulation by man and livestock.

\section{The aims of environmental management}

Environmental management had been applied before transmission of parasitic diseases was understood and even before the causative agents were known (Russell, 1955). Various authors expressed doubts about lasting effectiveness of newly developed, widely advertised control methods from time to time and called attention to the complementary part environmental management could play. However, environmental management was revived recently and took the following definitions:

Environmental management, as given in the coverpage of the International Journal Environmental Management (1984) founded in 1976, is committed to the principle of stewardship, the moral and intellectual obligation to seek knowledge that helps protect and sustain our world and all its life. Stewardship fosters a reference and respect for the environment, its life, its processes, so that the world can be passed on unmarred to future generations.

For the more restricted purposes of this presentation the definitions will be used as outlined by a group of experts, specially commissioned by
WHO (1982) and taken up subsequently by other international organizations (Mather and Trinh, 1984) or by consortia of international organizations (PEEM, 1984). Accordingly, "Environmental management for vector control" is defined as: the planning, organization, carrying out and monitoring of activities for the modification and/or manipulation of environmental factors or their interaction with man with a view to preventing or minimizing vector propagation and reducing man-vector-pathogen contact (WHO, 1982).

Environmental management covers three components: (1) the permanent or long term modification of land, water or vegetation, (2) recurrent manipulations to produce temporary conditions unfavourable to vector breeding, and (3) the modification or manipulation of human habitation or behaviour (Mather and Trinh, 1984).

In this context three things ought perhaps to be pointed out: (1) the third component mentioned of environmental management deals with human behaviour. This expression means much more than just provision of mechanical barriers against vectors, water supply etc.; behaviour touches on "Weltanschauung", human elements rooted most deeply, expressed by beliefs and customs, and thus most difficult and, above all, most delicate to alter. (2) There are no clear cut delimitations of environmental management as opposed to classical hygiene, to biological control, to genetic engineering (applied to either animals, including vectors, or plants), or even to the application of pesticides, especially when these

Table 1. Population growth, 1984-2000

\begin{tabular}{lccc}
\multicolumn{4}{c}{ Table 1. Population growth, 1984-2000 } \\
\hline & $\begin{array}{c}\text { Estimated } \\
\text { population, } \\
1984\end{array}$ & $\begin{array}{c}\text { Expected } \\
\text { annual growth } \\
(\%)\end{array}$ & $\begin{array}{c}\text { Extrapolated } \\
\text { population, } \\
2000\end{array}$ \\
\hline World & 4762 & 1.7 & 6250 \\
Developing countries & 3596 & 2.1 & 4980 \\
Africa & 531 & 2.9 & 855 \\
Asia & 2782 & 1.8 & 3680 \\
Latin America & 397 & 2.4 & 562 \\
Industrialized nations & 1166 & 0.6 & 1270 \\
\hline From: World Population
\end{tabular}

World Population Data Sheet (1984); Population Reference Bureau Inc. Washington (1984); Leisinger (1985). 
are of natural origin, i.e. from plants or from microorganisms. Environmental management represents a way of looking at things, rather than a method. As such it is but one part of an integrated approach to the control of diseases. (3) Even the recent literature on environmental management contains little or no indications on criteria for success or failure, or the degree of either one. While applied drug research, for example, provides easily quantifiable results, those obtained with environmental management are much more difficult to assess since environmental management as a rule is an integrated part of control measures. Yet, in order to estimate the cost/benefit ratio, criteria will have to be defined, e.g. the reduction of mosquito larvae or aquatic snails at particular points of a water body.

\section{DISEASES CONCERNED}

All those parasitic diseases, the prevalence and incidence of which are likely to be notably affected by either modifications or manipulations of the environment, or by changes of human behaviour are considered in Table 2. The taxonomic status of the parasite, be it protozoan or otherwise, is of secondary importance compared to its mode of transmission, especially when vectors, intermediate hosts or other animals are involved, whose biology must be thoroughly understood before meaningful actions can be undertaken. Particularly good examples are mosquitoes which, besides malaria, transmit viral and helminthic diseases; or mosquito-borne diseases and schistosomiasis, both water-bound, and consequently, favoured by the same environmental conditions. Environmental management furthermore, may affect man as well as synanthropic and wild animals, both possibly acting as reservoirs or as intermediate hosts of disease. In order to get the best results possible, environmental management must take a multi-disease approach, where the diseases to be controlled are selected according to transmission patterns, irrespective of whether they concern man or animals.

\section{ENVIRONMENTAL MANAGEMENT AS PRESENTLY APPLIED}

\section{Intestinal protozoan diseases}

As indicated in Table 2 all of the more frequent intestinal protozoans are transmitted by the faecooral route, cysts being the parasite forms ingested. Prevention consists of measures such as the use of latrines, properly built and maintained, the provision of water, the adequate preparation of food, personal hygiene and the like. Such precautions clearly belong to what is called hygiene; the construction of latrines however, or rather the selection of their sites, and the proper construction of wells represent environmental modifications which, incidentally, are often not properly undertaken due to lack of education and of stimulation. In addition, environmental manipulations, such as the proper disposal of refuse, may help to keep the number of flies and cockroaches low. So, as has been said before, there is an area of overlap between hygiene and environmental management.

\section{Toxoplasmosis}

The situation is similar for Toxoplasma gondii, except that cats and synanthropic rodents are involved too. Additional manipulations of the environment are recommended, e.g. the covering of sandboxes for childrens play (Szabo, 1974). Here again, health education and stimulation of the human population concerned will be decisive factors.

\section{Hydatid disease}

Although not of protozoan origin hydatid disease may be mentioned here since it too is closely linked to domestic animals. Extensive work has been carried out in the more recent past (Mann, 1978; Mac-

Table 2. Protozoan and other agents pathogenic to man and cattle likely affected by Environmental Management

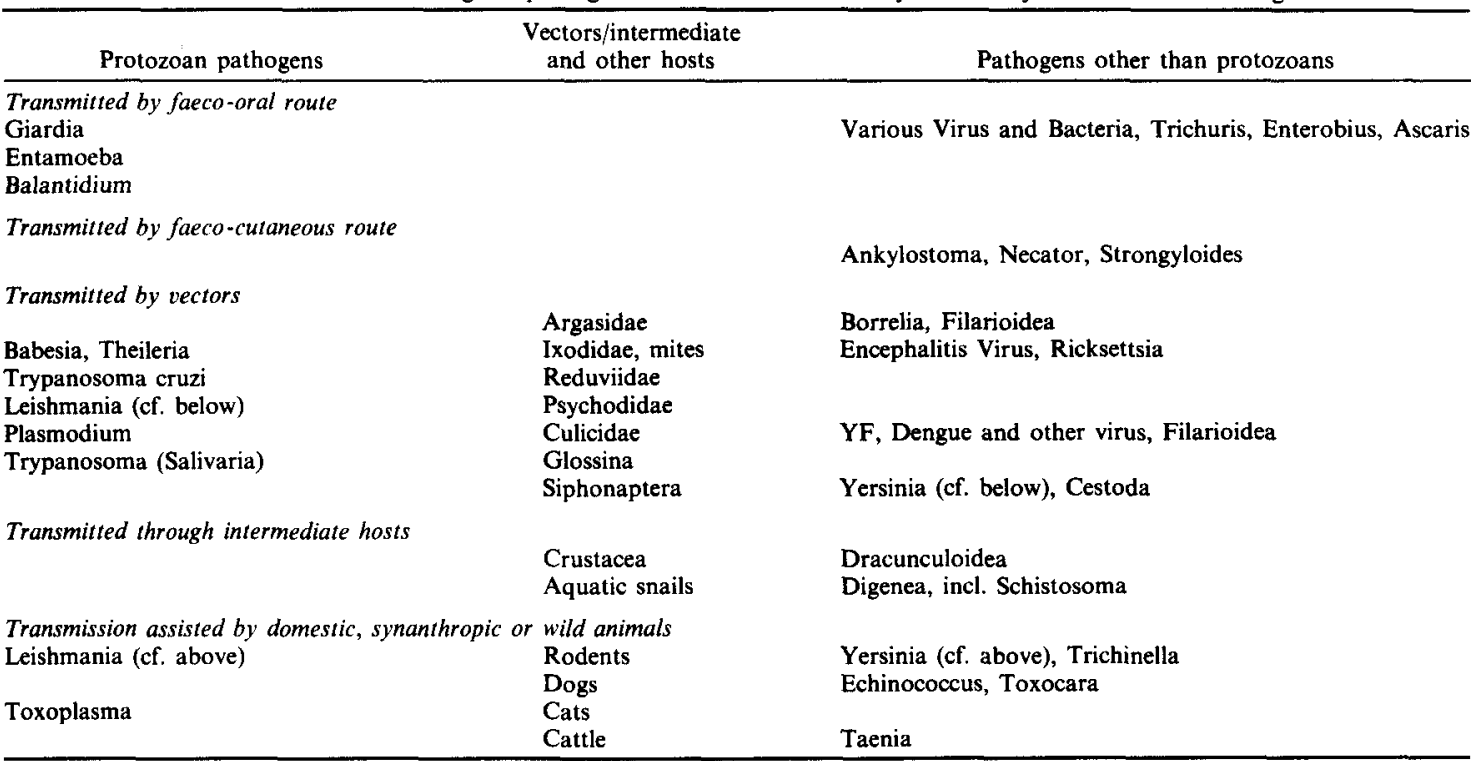


pherson, 1985) and a pilot project is now underway in north-western Kenya which hopefully will show whether "dog dosing" and preventing dogs gaining access to infected material (e.g. in cemeteries), become possible when the human population concerned actively participates in the programme (Macpherson et al., 1984). It is a remarkable project because, from its inception in the 1970 s it was understood that for each eco-region specific solutions must be sought based on local studies and taking both the parasite and the environment into consideration (Mann, 1978). It has been clearly recognized that the relationship between the domestic cycle and the wild life cycle operating in the same area requires further study (Macpherson, 1985) and, even more important, that without the help and co-operation of the local population the chances of controlling the disease would be slim (Macpherson et al., 1984).

\section{Chagas' disease}

Housing conditions are the crucial element with regard to prevention of Chagas' disease because its vectors, various species of haematophagous reduviid bugs, mainly occur in simple dwellings, frequently made of adobe. The Brazilian Government initiated a housing construction project to control the disease, which however failed, not because the houses built were not free of vector bugs, but because the people for whom they had been erected, found it impossible to accept their new houses. Dias and Dias (1982) who investigated the possibilities of controlling Chagas' disease in the state of Minas Gerais, concluded that housing involves more than a home's four walls, because the environment around and within it does affect people and contributes to their level of health. They even went so far to conclude that, ultimately, control of Chagas' disease may depend upon the gradual evolution and modification of rural society.

\section{East Coast fever, babesioses and other tick-borne} diseases

The situation is rather different with reference to tick-borne diseases such as East Coast fever, the various babesioses, anaplasmosis and heart-water, mainly because cattle and their vast grazing grounds are involved. Not only has the application of acaricides been found to be of limited value and genetic manipulation or pheromone attractants shown little promise, but well established principles such as pasture rotation and the alteration of vegetation are said to have had little impact on tick control. Wharton (1976) suggests as an alternative that use be made of naturally evolved host-parasite relationships, i.e. to capitalize on immunity of cattle towards ticks. He also calls attention to game ranching, the domestication and harvesting of game (King and Heath, 1975).

Pasture rotation and alteration of vegetation, both methods of environmental management, by themselves are obviously insufficient; they must be combined with other control measures, e.g. with the use of natural defence mechanisms. These might be supported by selective cattle breeding techniques, provided the naturally occurring immune responses, resistance to ticks, are better understood both in the laboratory (Papatheodorou, 1985) and in the field (Dhadialla, 1984).

\section{Tsetse-borne trypanosomiases}

Somewhat comparable problems are met within tsetse-borne trypanosomal diseases, although there are important differences in the transmission of human sleeping sickness as opposed to nagana in cattle (Ormerod, 1976). By and large, environmental management, including the clearing of vegetation and the destruction of game animals (!), is considered as having had little effect on tsetse populations (Rogers and Randolph, 1985), the only efficient way for temporary reduction formerly having been the application of insecticides (Jordan, 1978). It seems that the more recently developed Challier and Laveissiere biconical trap, too, may lead to interruption of transmission, at least where riverine tsetse species are the responsible vectors (Dame and Jordan, 1981; Langley, 1983; Rogers and Randolph, 1985). Only under very restricted conditions may the clearing of vegetation be helpful, e.g. along the main tourist tracks in order to protect visitors from abroad from getting infected (Geigy, 1974) and, to a lesser extent, game wardens and park personnel. On the other hand, various authors have discussed the implications that successful tsetse control would be likely to have (Ormerod, 1976; Jordan, 1978; Lawrence et al., 1980; Perich, 1982). Although they do not share the same views with regard to the actions to be undertaken, they all agree in saying that effective large-scale tsetse reduction would have far-reaching consequences, by changing topography and climate of large parts of Africa either because of overgrazing (Ormerod, 1976) or by alterations of land usage (Jordan, 1978). It has even been claimed that in countries such as Burundi, irrespective of the success of tsetse control, human population growth will lead to changes of the landscape which will necessarily cause the disappearance of tsetse (Perich, 1982). Whatever will be the case, it seems evident that in the context of tsetse-borne trypanosomal diseases large scale environmental changes must be expected which, in turn, will profoundly affect the living conditions of man, unless Rogers and Randolph (1985), who suggest the survival strategy of Glossina to be of such efficacy as to overplay whatever control measures man is to apply, are right.

\section{Leishmaniases}

Observation of a similar nature have already been made in the vast land-reclamation areas of some southern Soviet Republics in Central Asia, where zoonotic cutaneous leishmaniasis until now has required considerable attention on the part of the Public health institutions. Anthroponotic cutaneous leishmaniasis however is no longer a problem, due to improved housing conditions, anti-malarial insecticiding and to specific measures of sandfly control (Kellina, 1981). Zoonotic cutaneous leishmaniasis has its natural foci in the area of the great gerbil distribution (Rhombomys opimus), the main natural host of Leishmania mujor. The area is identical with the territories selected for development. Irrigation has greatly improved conditions favourable for Phlebotomus papatasi. Many people who move into the 
area are non-immunes, so that outbreaks of the disease readily occur. Environmental modifications, conversion of land for agricultural purposes and irrigation, have lead to a substantial increase of natural host-vector-man-contact. Environmental manipulations, mainly ploughing, are now being used to counteract these detrimental effects by destroying the burrows of the main natural host.

As for visceral leishmaniasis in rural areas, cases are still recorded annually, while in urban areas the disease has disappeared due to the detection and treatment of patients, destruction of dogs and site specific application of DDT. It is suspected that in rural areas transmission of the parasite from wild animals to man is the main cause for the difficulties encountered in controlling visceral leishmaniasis (Kellina, 1981).

\section{Malaria and schistosomiases}

Malaria and schistosomiases are being dealt with together in this presentation because they are both bound to water, often to the same water bodies, and because the most detailed literature about environmental management exists with reference to these two groups of diseases (WHO, 1982; Mather and Trinh, 1984). It will suffice here to mention that one (WHO, 1982) deals with mosquito control at all levels of human enterprise, while the second one (Mather and Trinh, 1984) refers particularly to rice fields.

With regard to schistosomiases, most valuable information has become available from various parts of the world, e.g. from Madagascar (Degremont, 1973), Tanzania (Fenwick, 1971; Marti et al., 1985), Puerto Rico (Negronaponte and Jobin, 1979), or Japan (Nihei et al., 1981). Relevant experience has been gained from the Lindu Valley project in Central Sulawesi, Indonesia (Dazo et al., 1976; Carney and Sudomo, 1980; Putrali et al., 1980), where an attempt was made to prevent schistosomiasis in a reclaimed rice cultivation area by combining agro-engineering or modification of the environment (drainage cum irrigation) with environmental sanitation (water supply, latrines), mollusciciding, chemotherapy and health education (Dazo et al., 1976). The intervention was shown to lower the human prevalence rate as well as the transmission of the disease (Putrali et al., 1980). In the long run, unfortunately, the project is being considered a failure, due to insufficient coordination of the efforts undertaken by a multitude of agencies including government authorities (Carney and Sudomo, 1980). This shortcoming might have been avoided had health education prior to control activities led to a sufficient degree of motivation on the part of the community (M. Sudomo, personal communication).

Very recently a detailed study was published dealing with snail control possibilities by environmental manipulation as applied to the Ibadan area, Nigeria (Thomas and Tait, 1984). It is also noteworthy that in some regions synthetic chemicals might soon be replaced by naturally occurring plant molluscicides (Marston and Hostettmann, 1985; Suter et al., 1986). If these were shown to be effective, environmental management would have to ensure conservation of the trees and plants concerned. Whatever will become possible, no single method will solve the problems, only a package of integrated measures may lead to success (Mott, 1984; Tanner, 1984; Ukoli, 1984).

As to malaria, integrated control is equally called for (Najera-Morrondo, 1979). This comprises chemotherapy and prophylaxis, reduction of man-vector contact by improving and spraying houses, by using mosquito nets and possibly repellents, and in more direct connection with environmental management, by reducing breeding sites-foremost the man-made ones-either by larviciding or by modifying and manipulating the environment. Manipulation here may include the use of larvivorous fish (Miura et al., 1984), the application of endotoxins of Bacillus thuringiensis $\mathrm{H}-14$, or perhaps of plant molluscicides acting as larvicides as well (N. J. Minjas, personal communication). Integrated control may also include early warning systems, such as the one recently studied in northern Thailand (Cullen et al., 1984). But whatever they advocate, most authors stress the necessity to seek solutions based on locally conducted investigations (Busvine, 1978; Hayes et al., 1985), to increase applied field research as a basis for a more thorough epidemiologic knowledge (NajeraMorrondo, 1979), and to set up appropriate health services (Bruce-Chwatt, 1983). They also underline the importance of adequate public information of health education (Ogunmekan, 1983) and of the active co-operation by the community (Fernando, 1983). In other words, effective malaria control will come true only if it proceeds pari passu with socioeconomic advance (Editorial, Lancet, 1983).

\section{MAN, THE FORGOTTEN FACTOR} (Gillett, 1985)

It has become abundantly clear that environmental management, although possibly an essential tool for the fight against some of the diseases reviewed, cannot be made use of alone, but that it is always only one part of a package, of which all elements are interlinked in a most complex manner. Environmental management, in particular, cannot be separated from socioeconomic factors and changes; it is most intimately linked with man and his way of life. While it may be true that hired labour will implement environmental modifications, it will almost invariably be the local residents who, in the long run, have to take care of manipulations and who will longest be affected by environmental management. The local residents, thus, represent the key factor for the success or failure of environmental management (Davis, 1981; Bobillier, 1985). Let us look at them and at the prerogatives for their lasting co-operation. (For convenience only rural smallholders will be considered, the situation in urban areas and in large-scale agricultural enterprises being somewhat different.)

Health education and stimulation of, and cooperation by, the local human population were mentioned. What do these expressions mean in actual life? How are rural societies to be modified, how do they evolve?

\section{Awareness}

Before anything one has to listen to the local people to find out what problems they see in life. Health matters may be found among them, but not 
necessarily at the top of the list (Behrhorst, 1983). Is the local population at all aware of any health related problem and, if so, what to them (the local residents) are the most pressing ones? Repeatedly morbidity studies have shown that although a particular infection was highly prevalent it was comparatively well tolerated and did, in fact, not represent an acute problem to the community investigated (Tanner et al., 1983).

It is pointless to try to impose changes in behaviour, even if scientifically sound surveys indicate their desirability, unless the local residents see the necessity themselves. If they do not agree with the priorities scientists set, they must be allowed to start with matters they feel to be important, and the health aims must be introduced gradually; if they do not see any necessity, leave them alone and address yourself to a neighbouring, more advanced community.

\section{Information}

To provide the necessary information is the next basic step (Imperato et al., 1976; Ogunmekan, 1983). This has to address all levels concerned, each one in the most appropriate fashion and through the best available channels. It makes little sense when expatriates address the grassroot farmer in exuberant speeches; it is more efficient for an expatriate to encourage the health officer in charge to take care of the information flow needed in his district through the various existing channels, the traditional ones, the health system, schools, Party and possibly others. (This does not mean that the elite, nationals and expatriates alike, should not have direct contact to the local population!) Information is also needed at the various levels of the administration. Often neglected are the members of the lower hierarchical levels, who are the ones who may render an action impossible if they do not feel that they are being treated properly. Information is needed at the top, as well. It is also, and sometimes badly, needed at the level of expatriate staff who may be experts in particular fields (irrigation, road construction etc.), but may miss the comprehensive view and, in particular, ignore the possibility of adverse effects of their well intentioned activities.

\section{Decision}

If adequate information may stimulate local people to become active, the possibility of taking a leading part when it comes to deciding on practical action may be the most important prerogative to ensure acceptability of whatever steps are to be undertaken. In addition, local populations know more about their own resources; they may act on the principle of self-reliance which, in turn, may promote the more extensive behavioural changes aimed at.

\section{Implementation}

Initial implementation, in principle, must rest with those who take the decisions, i.e. ideally with the local population. But, it may need material support and encouraging supervision from external sources, governmental or non-governmental, depending on the scope of the actions at stake.

\section{Evaluation}

Those who have made decisions, and then taken action want to see results; otherwise they lose the motivation to keep going ahead. Thus, evaluation must follow initial actions, the results of which ought to be discussed both with those who took the decisions and with the supporting agencies alike.

\section{Renewed decision}

This feedback will lead all concerned to decide on further actions, to be amended according to the experience gained, thus ensuring further feasibility and acceptance.

\section{Renewed evaluation}

The ongoing interplay of renewed decision and evaluation, sustained by evolving information and health education, will help avoid loss of interest and provide conditions for efficient maintenance.

\section{Maintenance}

This may become a routine, it may also lead to a point where activities may be discontinued because the original aims are attained, or because the environment and human behaviour have changed to such an extent that the activities become redundant.

In short, environmental management must be undertaken by the local residents themselves. In order to ensure maximum participation, the local population has to become aware of its own problems, must be offered relevant information, has to decide on and to implement the first action itself and must be helped to evaluate the results obtained. External agencies: governmental, non-governmental, national and international, ought to participate, not by imposing solutions but mainly by active encouragement. Their experts, qualified and experienced, can contribute to growing awareness, must provide sound information, based on locally conducted surveys, can promote decisions, may support implementation, and ought to be involved in longitudinal evaluation. They have an important role to play, preferably one of unobtrusive assistance.

\section{SUMMARY AND CONCLUSIONS}

\section{Environmental management}

Is an essential tool to maintain or regain man-parasite equilibrium.

Is closely interrelated with all aspects of human life and to the development of societies.

Is but one part of health promoting activities, into which it has to be integrated.

Must meet the priorities perceived by the local population.

Must be handled by the local populations, and merely be assisted by external agencies.

Must be tailor-made, i.e. adapted to local conditions.

Must follow a multi-disease approach, depending on transmission patterns.

Environmental management, whether it is undertaken or not, and how it is handled, is an index for the evolution of human societies. 
Acknowledgements - Sincere thanks are due to Dr Marcel Tanner for stimulating discussions on the subject of this paper, and to Professor Leo Jenni and Dr David Jefferies for reading the manuscript and amending a Continental's faulty English.

\section{REFERENCES}

Behrhorst C. (1983) Health in the Guatemalan Highlands, Vol. xi-xii. University of Washington Press, Seattle.

Bobillier C. W. (1985) The training of villagers and community participation in the Sahel: a case study of Burkina Faso's Villages. Ph.D. thesis, University of London.

Bruce-Chwatt L. J. (1983) Malaria control and primary health care: or the art of squaring the circle. Bull. Soc. Path. exot. 76, 477-485.

Busvine J. R. (1978) Current problems in the control of mosquitoes. Nature 273, 604-607.

Carney W. P. and Sudomo M. (1980) Schistosomiasis in Indonesia, 1980. Symp. Masalah Penyakit Parasit. 58-63.

Cullen J. R., Chitrarop U., Doberstyn E. E. and Sombatwattanangkul K. (1984) An epidemiological early warning system for malaria control in northern Thailand. Bull. WHO 62, 107-114.

Dame D. A. and Jordan A. M. (1981) Control of tsetse flies Glossina ssp. Adv. vet. Sci. comp. Med. 25, 101-119.

Davis A. (1981) Principles of schistosomiasis control in relation to community health care. ArzneimittelForsch./Drug Res. 31, 616618 .

Dazo B. C., Sudomo M., Hardjawidjaja L., Joesoef A. and Bardoji A. (1976) Control of Schistosoma japonicum infection in Lindu valley, Central Sulawesi, Indonesia. S.E. Asian J. trop. Med. publ. Hith 7, 330-340.

Degrémont A. A. (1973) Projet Mangoky, Lutte Contre Les Schistosomiases dans le Bas-Mangoky (Madagascar). Institut Tropical Suisse Bâle.

Dhadialla T. S. (1984) Immunomanipulation of Tick Hosts as a Potential Tick Control Method. DUDU, News from the ICIPE, Third Quarter 1984, No. 29.

Dias J. C. P. and Dias R. B. (1982) Housing and the control of vectors of human Chagas' disease in the state Minas Gerais, Brazil. Paho Bull. 16, 117-129.

Editorial (1983) Malaria control and primary health care. Lancet 30, 963-964.

Environmental Management (1984) Int. J. Decis. Makers Scient. 8, 4.

Fenwick A. (1971) The control of Schistosoma mansoni on a sugar estate in Tanzania. East Afr. med. J. 48, 447-449.

Fernando M. A. (1983) Social and economic aspects of tropical diseases and control. S.E. Asian J. trop. Med. publ. Hlth 14, 8-11.

Geigy R. (1974) Klimatische und hygienische Umwelteinflüsse auf Mensch und Tier in den Tropen. Bull. schweiz. Akad. med. Wiss. 30, 186-193.

Gillett J. D. (1985) The behaviour of Homo sapiens, the forgotten factor in the transmission of tropical diseases. Trans. R. Soc. trop. Med. Hyg. 79, 12-20.

Hayes R. O., Maxwell E. L.., Mitchell C. J. and Woodzick T. L. (1985) Detection, identification and classification of mosquito larval habitats using remote sensing scanners in earth-orbiting satellites. Bull. WHO 63, 361-374.

Imperato P. J., Fofana B. and Sow O. (1976) Incidence of and beliefs about trypanosomiasis in the Senegal River Basin. Acta trop. 33, 223-228.

Jordan A. M. (1978) Principles of the eradication or control of tsetse flies. Nature 273, 607-609.

Kellina O. I. (1981) Problem and current lines in investigations on the epidemiology of leishmaniasis and its control in the U.S.S.R. Bull. Soc. Path. exot. 74, 306-317.

King J. M. and Heath B. R. (1975) Game domestication for animal production in Africa. Wld Anim. Rev. 16, 23-30.

Langley P. A. (1983) Tsetse flies: vectors of the African Trypanosomiasis. Biologist 30, 281-287.
Lawrence J. A., Foggin C. M. and Norval R. A. I. (1980) The effects of war on the control of diseases of livestock in Rhodesia (Zimbabwe). Vet. Rec. 107, 82-85.

Leisinger K. M. (1985) Soziale Voraussetzungen für kleinere Familien in der Dritten Welt. Social Strat. 1, 44.

Macpherson C. N. L. (1985) Epidemiology of hydatid disease in Kenya: a study of the domestic intermediate hosts in Masailand. Trans. R. Soc. trop. Med. Hyg. 79, 209-217.

Macpherson C. N. L., Zeyhle E. and Romig T. (1984) An Echinococcus pilot control programme for northwest Turkana, Kenya. Ann. trop. Med. Parasit. 78, 188192.

Mann I. (1978) Integrated multidisciplinary environmental approach to the study of taeniasis and echinococcosis. Ann. Ist. Super. Sanità 14, 235-244.

Marston A. and Hostettmann K. (1985) Plant Molluscicides. Phytochemistry 24, 639-652.

Marti H. P., Tanner M., Degremont A. A. and Freyvogel T. A. (1985) Studies on the ecology of Bulinus globosus, the intermediate host of Schistosoma haematobium in the Ifakara area, Tanzania. Acta trop. 42, 171-187.

Mather T. H. and Trinh Ton That (1984) Environmental management for vector control in rice fields. FAO Irrigation and Drainage Paper Vol. 41.

Miura T., Takahashi R. M. and Wilder W. H. (1984) Impact of the mosquitofish (Gambusia affinis) on a rice field ecosystem when used as a mosquito control agent. Mosquito News 44, 510-517.

Mott K. E. (1984) Schistosomiasis: a primary health care approach. WHO Forum 5, 221-225.

Najera-Morrondo J. A. (1979) A suggested approach to malaria control and to the methodology applicable in different epidemiologic situations, based on experience in the Americas. Bull. Pan. Am. Hlth Organ 13, 223-233.

Negron-Aponte H. and Jobin W. R. (1979) Schistosomiasis control in Puerto Rico. Twenty-five years of operational experience. Am. J. trop. Med. Hyg. 28, 515-525.

Nihei N., Asami S. and Tanaka H. (1981) Geographical factors influencing the population numbers and distribution of Oncomelania nosophora and the subsequent effect on the control of schistosomiasis japonica in Japan. Soc. Sci. Med. 15D, 149-157.

Ogunmekan D. A. (1983) Control of malaria with special reference to socioeconomic factors. Trop. Doct. 13, $185-186$.

Ormerod W. E. (1976) Ecological effect of control of african trypanosomiasis. Science 191, 815-821.

Papatheodourou V. (1985) Réaction immunitaire du lapin contre la tique Ixodes ricinus: effets sur la composition et la digestion du repas sanguin. Thèse Université de Neuchâtel.

PEEM (1984) Report on the Fourth Meeting. WHO/FAO/ UNEP, VBC 84.5 , p. 82.

Perich P. (1982) Les foyers de trypanosomiase humaine africaine à Trypanosoma rhodesiense (vecteur Glossina morsitans) au Burundi. Méd. trop. 42, 33-41.

Putrali J., Dazo B. C., Hardjawidjaja L., Sudomo M. and Barodji A. (1980) A schistosomiasis pilot control project in Lindu valley, Central Sulawesi, Indonesia. S.E. Asian J. trop. Med. publ. Hlth 11, 480-486.

Rogers D. J. and Randolph S. E. (1985) Population ecology of tsetse. A. Rev. Ent. 30, 197-216.

Russell P. F. (1955) Man's Mastery of Malaria. Oxford University Press, London.

Suter R., Tanner M., Borel Ch., Hostettmann K. and Freyvogel T. A. (1986) Laboratory and field trials at Ifakara (Kilombero District, Tanzania) on the plant molluscicide Swartzia madagascariensis. Acta trop. 43, 69-83.

Szabo T. (1974) The present state of toxoplasmosis. Mount Sinai J. Med. 41, 765-773.

Tanner M. (1984) Aspects Techniques de la Lutte Contre la 
Schistosomiase, pp. 124-125. Deutsche Gesellschaft für Technische Zusammenarbeit (GTZ) GmbH, Eschborn.

Tanner M., Holzer, B., Marti H. P., Saladin B. and Degremont A. (1983) Frequency of haematuria and proteinuria among Schistosoma haematobium infected children of two communities from Liberia and Tanzania. Acta trop. 40, 231-237,

Thomas J. D. and Tait A. I, (1984) Control of the snail hosts of schistosomiasis by environmental manipulation: a field and laboratory appraisal in the Ibadan area, Nigeria Phil. Trans. R. Soc. Lond. B305, 201-253.

Ukoli F. M. A. (1984) Introduction of Parasitology in Tropical Africa, Vol. 73. Wiley, New York.

Wharton R. H. (1976) Tick-borne livestock diseases and their vectors. Wld Anim. Rev. 20, 8-15.

WHO (1982) Manual on environmental management for mosquito control with special emphasis on malaria vectors. WHO Offset Publ. Vol. 66. 